\title{
Estimating the Rate of Azithromycin Degradation Due to Increasing Temperature for Three Drug types by Spectrophotometer (UV) and Gas Chromatography-Mass Spectrometry (GC-MS)
}

\author{
MAHA ABDALLAH ALNUWAISER*
}

\author{
Department of Chemistry, College of Science, Princess Nourah Bint Abdulrahman University, \\ P.O. Box 28445, Riyadh-11437, Saudi Arabia. \\ *Corresponding author E-mail: maalnoussier@pnu.edu.sa \\ http://dx.doi.org/10.13005/ojc/370215
}

(Received: February 25, 2021; Accepted: April 03, 2021)

\begin{abstract}
Azithromycin is a board antibiotic that affects various Gram-positive and Gram-negative bacteria, so azithromycin is used for the treatment different of bacterial infections, as well as used azithromycin as a prophylactics antibiotic after different surgeries. Azithromycin is used for children and adults, so it is available in pharmacies in different dosage forms like capsules, tablets, powder for reconstituting for oral administration. The aims of the present research is to assess the azithromycin stability from different available dosage forms (bioequivalence study) against temperature in hot climate country (Saudi Arabi). Three samples in the form of three drugs in which Azithromycin acts as an active ingredient were prepared and exposed to heat. These drugs are Azithromycin ${ }^{\circledR} 250 \mathrm{mg}, \mathrm{Az}-1^{\circledR} 250 \mathrm{mg}$, and Zirox ${ }^{\circledR}$ $250 \mathrm{mg}$. Three spectral techniques were used to study the change in concentration and chemical composition when the temperature is raised from $27^{\circ} \mathrm{C}$ to $60^{\circ} \mathrm{C}$. The spectrometers used are ultraviolet Spectrometer and Gas Chromatography and Mass Spectrometry. The temperature of the three drugs was raised from $27^{\circ} \mathrm{C}$ to $60^{\circ} \mathrm{C}$ inside the water path. The ultraviolet spectrometer shows considerable degradation in Azithromycin concentration but the other two drugs are not affected appreciably by heating. The results obtained using the retention time technique of gas chromatography, show a change of the retention time to be (20.308-20.396-20.350) for Azithromycin ${ }^{\circledR}, A z-1{ }^{\circledR}$, and Zirox ${ }^{\circledR}$ scanned, $^{2}$ respectively. This change may result from the difference in the matrix chemical composition of each drug. The mass spectrometry results show that rising temperature to $60^{\circ} \mathrm{C}$ the chemical bonds of the active ingredient to be decomposed to five compounds having $\mathrm{m} / \mathrm{z}$ (43-72-99-158-198), respectively.
\end{abstract}

Keywords: Azithromycin, Chemical stability, Temperature degradation, Bioequivalence study, Gas Chromatography and Mass Spectrometery.

\section{INTRODUCTION}

Azithromycin is a board antibiotic that affects of three various Gram-positive and Gram-negative bacteria, so the azithromycin used for the treatment different of bacterial infections as middle ear infections, strep throat, pneumonia, traveler's diarrhea, and certain other intestinal infections. In addition, azithromycin

This is an Open Access article licensed under a Creative Commons license: Attribution 4.0 International (CC- BY). Published by Oriental Scientific Publishing Company @ 2018

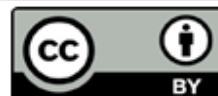


effective against many sexually transmitted infections as including chlamydia and gonorrhea infections. Azithromycin is one of the medicine that can be used for kids, so it is prepared as a powder for reconstituting, in addition to capsule and tablets dosage form, usually, azithromycin dosage regiment as once daily so many doctors and clinics advised it in many bacterial infection states as well as prophylactics antibiotics after surgery ${ }^{1}$.

Chemically, Azithromycin [9-deoxo-9a-aza9a-methyl-9a-homoerythromycin] belongs to the azalide subclass of the macrolides group (see Fig. 1), which contains a 15-membered ring, with methylsubstituted nitrogen instead of a carbonyl group at the 9a position on the aglycone ring, which allows for the prevention of its metabolism ${ }^{1,2}$.

Pharmacologically, the mechanism of action is interacting with bacteria protein synthesis, leading to prevents of bacteria growth. Also, inhibits mRNA translation ${ }^{3-5}$. Macrolides (Azithromycin belong family) drugs are active against bacteria and reinforce the immunity system ${ }^{6}$. So, the maintenance treatment with macrolides is a choice in the treatment of cystic fibrosis, bronchiectasis besides diffuse parochialities $^{7-12}$.

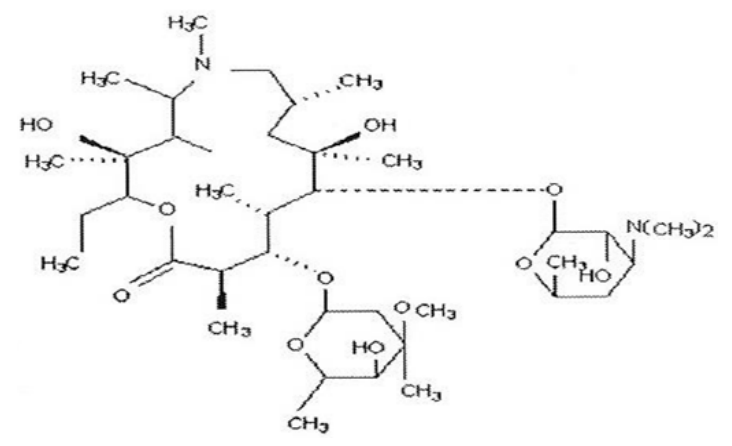

Fig. 1. Chemical structure of the azithromycin

Azithromycin is used in chronic obstructive pulmonary disease and neutrophilic airway disease ${ }^{12-14}$. In U.S.A azithromycin is an essential antibiotic ${ }^{12}$. The chemical composition and structure of azithromycin can be determined using liquid chromatography ${ }^{16,17}$. Some researchers use other techniques like mass spectrometer ${ }^{18,19}$ or differential poise ultra-metric device, for analysis of azithromycin ${ }^{20-22}$. Also, amperometry device ${ }^{23}$ or diffuse reflectance meter, infrared spectrometry is not analytically useful|24,25. There are other many spectrophotometric techniques based on the visible spectrum that can also be used in Azithromycin studies $^{26,27}$. Fortunately, recent spectral techniques have proved to be more accurate, fast, and of relatively low $\operatorname{cost}^{28-30}$.

\section{Methodology Study Design}

The present study is a bioequivalence study, that investigates the stability of different three azithromycin dosage forms (Azithromycin ${ }^{\circledR}$ $250 \mathrm{mg}, \mathrm{Az}-1^{\circledR} 250 \mathrm{mg}$, and Zirox ${ }^{\circledR} 250 \mathrm{mg}$ ) against the raised in temperature by chemical analysis of active ingredient concentration of each forms using Gas chromatography-mass spectrophotometric instruments.

\section{Source of Samples}

The samples were collected from three different bioequivalence dosages form Azithromycin ${ }^{\circledR}$ $250 \mathrm{mg}, \mathrm{Az}-1^{\circledR} 250 \mathrm{mg}$, and Zirox ${ }^{\circledR} 250 \mathrm{mg}$.

The present study has taken into consideration to grouped the same batch from each dosage form for methodology.

\section{Samples Collection}

The present study focused on three different azithromycin dosage forms that available in Saudi Arabia Pharmacy, the following: Azithromycin ${ }^{\circledR} 250$ $\mathrm{mg}, \mathrm{Az}-1^{\circledR} 250 \mathrm{mg}$, and Zirox ${ }^{\circledR} 250 \mathrm{mg}$, the sample collected from each dosage forms after exposure raised in temperature.

\section{Instruments}

A Shimadzou GC-MS/MS (TQ8040) was used with capillary column $(30 \mathrm{~cm} \times 0.25 \mathrm{~mm} \times 0.25$ $\mu \mathrm{m}),(5 \%$ phenyl-95\% dimethyl) (RTX-5), carrier gas helium (99.999\% purity), constant flow $1.22 \mathrm{~mL} / \mathrm{min}$, temperature program $50: 1 \%$ min to $120: 10 \%$ min to $200: 10 \% \mathrm{~min}, 280: 10 \% \mathrm{~min}$ final hold (22), Ion Source Temp $200^{\circ} \mathrm{C}$, Interface Temp $250^{\circ} \mathrm{C}$.

A Shimadzu UV-1800 Series technique was employed having a wavelength range of 200-400 nm, having also light source change wavelength (340.8 nm).

\section{UV Analysis}

Sample's Dilution: $0.5 \mathrm{~g}$ of each sample was weighed and put into a $100 \mathrm{~mL}$ volumetric flask. 
The volume was completed to $100 \mathrm{~mL}$ of isopropanol solution (A). $0.5 \mathrm{~mL}$ of this solution was transferred into a $50 \mathrm{~mL}$ volumetric flask and again diluted up to the mark of the flask using the isopropanol solution (B). Scanning and read of the absorption in UV device was done for all samples.

Exposure to Temperature: the amount of solution (B) for each sample was kept at $60^{\circ} \mathrm{C}$ for one hour than reading using UV device was made.

For each sample, the amount of sample solution was injected into the UV device. The absorbance and wavelength was them measured. A relation between absorbance and wavelength was displayed graphically (Table 1).

Table 1: Peaks of Azithromycin samples using UV-spectrophotometric between 200-400 nm
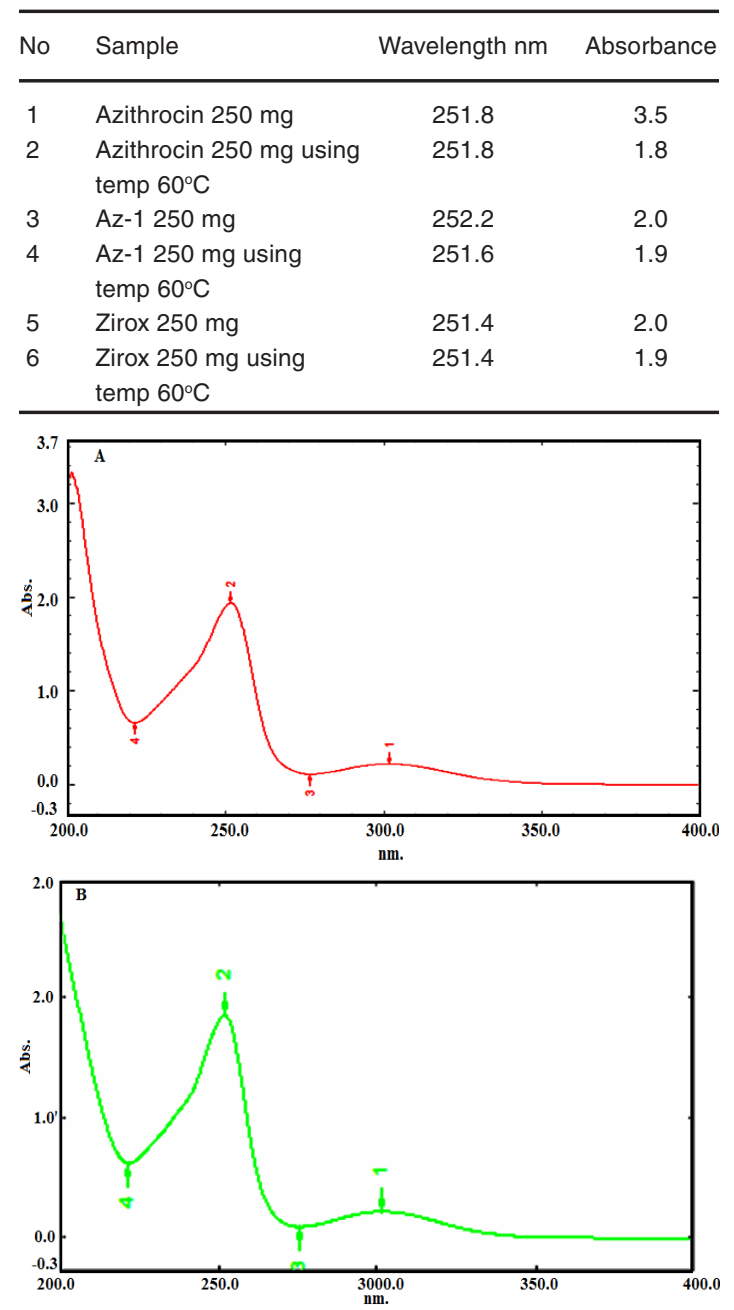

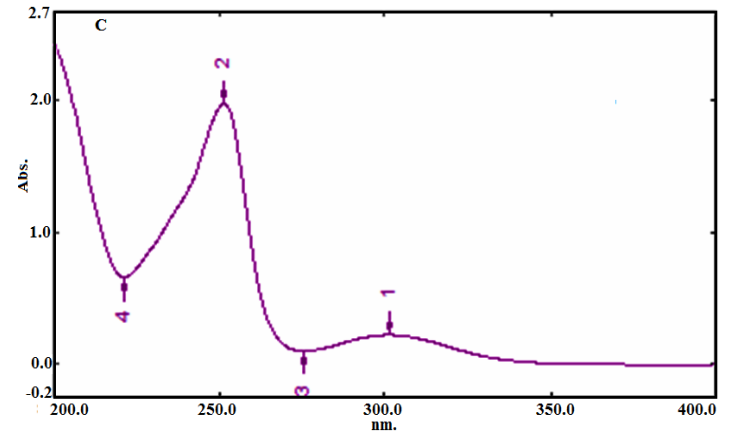

Fig. 2. UV spectrophotometric scanning between 200-400 $\mathrm{nm}$ for Azithrocin (A), Az-1 (B), Zirox (C) samples at $60^{\circ} \mathrm{C}$ temperature

\section{GC-MS analysis}

Sample's processing: A $0.01 \mathrm{~g}$ from each capsule were weighed and placed in a $10 \mathrm{~mL}$ volumetric flask, then $10 \mathrm{~mL}$ of methyl alcohol (HPLC grade) was added to each sample. The contents of each sample were mixed by a magnetic stirrer. The mixture was filtered, then the filtrate was subjected to GC-MS analysis. For each sample, $1 \mu \mathrm{l}$ was injected and a chromatography run was made. The chromatogram data was scanned and recorded in Fig. 2. The retention time was measured for each sample and compared with the library. The retention times (Rt) were measured for each sample and their results are given in Table (2).

Table 2: Relation time (Rt) and Mass per Atomic Number $M / z$ of caffeine in different azithromycin samples

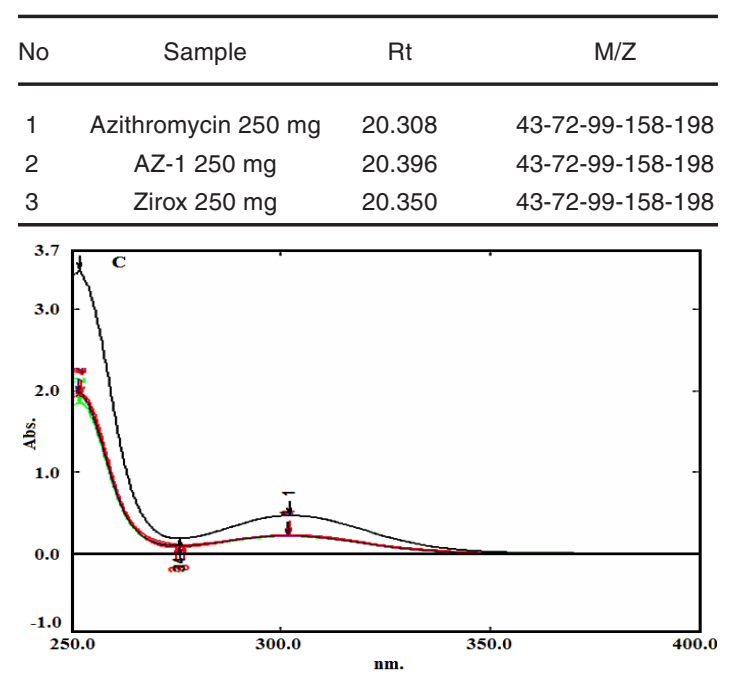

Fig. 3. UV spectrophotometric scanning between 200-400 nm for Azithrocin, $A_{z}-1$, Zirox samples at room temperature 


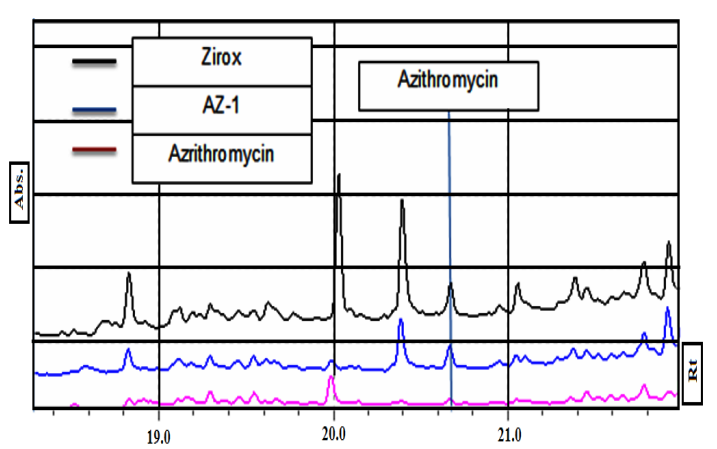

Fig. 4. Retention time versus absorption for Azithromycin, $A z-1$, and Zirox

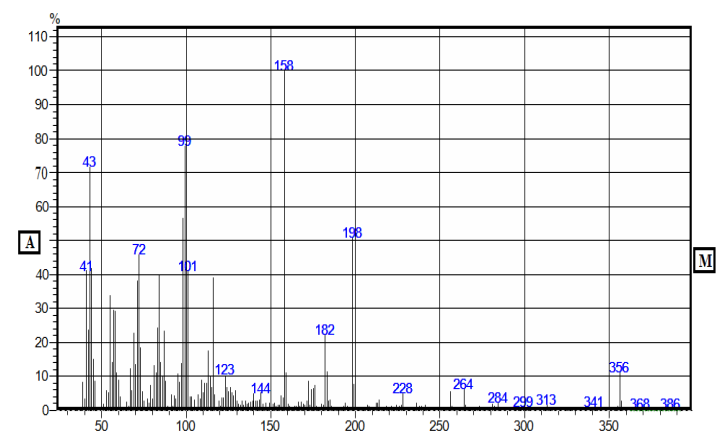

Fig. 5. Mass spectrophotometric: Molecular Weight (M) versus absorbance $(A \%)$

\section{RESULTS AND DISCUSSION}

In this work, the effect of heating and raising of temperature on the active ingredient for three drugs has been studied. These drugs are Azithromycin $250 \mathrm{mg}, \mathrm{Az}-1250 \mathrm{mg}$, and Zirox 250 $\mathrm{mg}$. the chemical analysis was achieved by using UV-spectrometer, Gas chromatography (GC), and mass spectrometry (MS). The Fig. 2-5 and Tables $(1,2)$ show the results.

In view of Fig. 2 beside Table (1), the UV spectrum shows a significant change in abundance (concentration) for azithromycin, where Table (1) shows that the absorption rate for wavelength 251.8 $\mathrm{nm} 3.5$ at room temperature $\left(27^{\circ} \mathrm{C}\right)$ is decreasing to 1.8 at $60^{\circ} \mathrm{C}$. This means the raising temperature to 60 causes considerable degradation of azithromycin. However, for the other two drugs, Az-1 $250 \mathrm{mg}$ and Zirox $250 \mathrm{mg}$, Fig. 2-5 indicate the azithromycin is almost unaffected by raising the temperature from $27^{\circ} \mathrm{C}$ to $60^{\circ} \mathrm{C}$.

Combined Gas chromatography and mass spectrometer (GC-MS) spectra for the three samples, shows the heating and raising in temperature degree of the three samples causes a considerable change in both absorption rate and chemical composition. The absorption rate versus retention time for azithromycin shows a very low absorption rate at $60^{\circ} \mathrm{C}$ compared to Az-1 $250 \mathrm{mg}$ and Zirox $250 \mathrm{mg}$. The mass spectrometry result for $\mathrm{m} / \mathrm{z}$ in the table (B) shows the azithromycin is fragmenting to separate compounds that having $\mathrm{m} / \mathrm{z}$ values $(43,72,99,158,198)$.

So, must be store the azithromycincontaining dosage form, at a temperature below $27^{\circ} \mathrm{C}$, to save their activity. The other two samples resist heating up to $60^{\circ} \mathrm{C}$.

The gas chromatography shows a change in the retention time of azithromycin in the three drugs, which assumes the values $(20.308,20.396$, 20.350) for, Az-1 and Zirox, respectively. This may be related to the matrix change of the drugs.

\section{CONCLUSION}

There are a significant impact of heating and raising of temperature degree in the stability of azithromycin $250 \mathrm{mg}$, when a raising the temperature from $27^{\circ} \mathrm{C}$ to $60^{\circ} \mathrm{C}$, but not impacting on Az-1 250 $\mathrm{mg}$ and Zirox $250 \mathrm{mg}$ dosage forms. This effect resulting in the degradation of the active ingredient (azithromycin) via the destruction of chemical bonds and produce of five different compounds (fragmentation). This fragmentation is observed for Az-1 and Zirox.

\section{ACKNOWLEDGMENT}

This research was funded by the deanship of scientific research at Princess Nourah Bint Abdulrahman University through the Fast-track Research Funding programme.

\section{Conflicts of Interest}

The author declares that there is no conflict of interest regarding the publication of this article. 


\section{REFERENCES}

1. Peters, DH.; Friedel, HA.; McTavish, D.; Azithromycin. A review of its antimicrobial activity, pharmacokinetic properties, and clinical efficacy. Drugs., 1992, 44(5), 750-99.

2. Fohner, AE.; Sparreboom, A.; Altman, RB.; Klein, TE: Pharm GKB summary: Macrolide antibiotic pathway, pharmacokinetics/ pharmacodynamics. Pharmacogenet Genomics., 2017, 27(4), 164-167.

3. Korolkovas, A.; Dicionario T. G. 6 ed Rio de Janeiro: Guanabara Koogan, 1999/2000, 159.

4. United States Pharmacopeia. 28.ed. Rockville: The United States Pharmacopeial Convention., 2005, 150-155.

5. Zanini, A.C.; Basilf, A, C.; Follador, W.; Oga, S. Guia De Medicamento. 2.ed, São Roque Ipex, 1997/1998, 180-182.

6. Crosbie, P.A.J.; Woodhead, M.A. Long-term macrolide therapy in chronic inflammatory airway diseases. Eur Respir, 2009, 33, 171-181.

7. Equi, A.; Balfour, L.; Bush, A.; Long-term azithromycin in children with cystic fibrosis: a randomized, placebo-comolled crossover trial. Lancet., 2002, 360, 978-984.

8. Davies, G.; Wilson, R. Prophylactic antibiotic treatment of bronchiectasis with azithromycin. Thorax., 2004, 95, 540-541.

9. Wong, C.; Jayaram, L.; Karalus, N.; Azithromycin for prevention of exacerbations in noncystic fibrosis bronchiectasis (EMBRACE: a randomised, double-blind, placebo- controlled trial. Lancet., 2012, 380, 660-667.

10. Koyama, H.; Geddes, D.M. Erythromycin and diffuse panbronchiolitis. Thorax., 1997, 52, 915-918.

11. Tran, D.H.; Sugamata, R.; Hirose, T.; Suzuki, S.; Noguchi, Y.; Sugawara, A.; Azithromycin a 15-membered macrolide inhibits influenza A (HINI pdm09 virus infection by interfering with virus internalization process. J. Antibiot., 2019, 72(10), 759-768.

12. Seemungal, T.A; Wilkinson, T.M; Hurst, J.R; Long. term. erythromycin therapy is associated with decreased chronic obstructive pulmonary disease exacerbations. Am. J. Respire. Crit. Care. Med., 2008, 178, 1139-1147.
13. Albert, R.K.; Connett, J.;Bailey, W.C.; Azithromycin for prevention of exacerbations of COPD. N. ENGL. J. Med., 2011, 365:689-698.

14. Brusselle, G.G; joos, G.G; Bracke, K.R. New insights into the immunology of chronic obstructive pulmonary disease. Lancet., 2011, 378, 1015-10126.

15. Giudicessi, J.R; Ackerman, M.J. Azithromycin, and risk of sudden cardiac death: guilty as charged or falsely accused? Cleve. Clin. J. Med., 2013, 80, 539-544.

16. Shaikh, K.A.; Patil, S.D.; Devkhile, A.B. Development and validation of a reversedphase HPLC method for simultaneous estimation of Ambroxol hydrochloride and azithromycin in tablet dosage form. J. Pharm. Biomed. Anal., 2008, 48, 1481-1484.

17. Yang, Z.Y.; Wang, L.; Tang, X. Determination of azithromycin by ion-pair HPLC with UV detection. J. Pharm. Biomed. Anal., 2009, 49, 811-815.

18. Debremaeker, D.; Visky, D.; Chepkwony, H.K.; Van, S.A.; Roets, E.; Hoogmartens, J. Analysis of unknown compounds in azithromycin bulk samples with liquid chromatography. Coupled to ion trap mass spectrometry. Rapid. Commun. Mass. Spectrum., 2003, 17, 342-350.

19. Breier, A.R.; Garcia, C.V.; Oppe, T.P. Steppe M. Schapoval, EE. Microbiological assay for azithromycin in pharmaceutical formulations. J. Pharm. Biomed. Anal., 2002, 29, 957-961.

20. Nigovic, B. Adsorptive stripping voltammetric determination of azithromycin at a glassy carbon electrode modified by electrochemical oxidation. Anal. Sci., 2004, 20, 639-643.

21. Farghaly, O.A.; Mohamed, N.A.; Voltammetric determination of azithromycin at the carbon paste electrode. Talanta., 2004, 62, 531-538.

22. Nigovic, B.; Simunic, B. Voltametric assay of azithromycin in pharmaceutical dosage forms. J. Pharm. Biomed. Anal., 2003, 32, 197-202.

23. Palomeque, M.E.; Ortiz, P.L. New automatized method with amperometric detection for the determination of azithromycin. Talanta., 2007; 72, 101-105. 
24. Ji, X.D.; Wen, B.Z.; Yan, C.F.; Dan, Q.S. Chang QH. Quantitative calibration models for the determination of azithromycin and Decladinosyl azithromycin in azithromycin injection powders using diffuse reflectance near infrared spectroscopy. J. Near. Infrared. Spectrosc., 2011, 19, 265-275.

25. Lakshmi, S.; Arul, M.M.; Jayashankar, L.; Ramu, P.; Raja, T.K.Visible spectrophotometric methods for the determination of azithromycin in tablets. Indian. J. Pharm. Sci., 2004, 66, 249-251.

26. Rachidia, M.; Elhartia, J.; Diguab, K.; Cherraha, Y.; Bouklouzea, A. New spectrophotometric method for azithromycin determination. Anal. Let., 2006, 39, 1917-1926.

27. Carlos, E.R.; Vanessa, G.K.; Ricardo, C.J. Spectrophotometric method for the determination of azithromycin in pharmaceutical formulations based on its charge transfer nest with quinalizain. J. Braz. Chan. Soc., 2010, 21, 1664-1671.

28. Saltara, N.; Araye, M.S.; Hussain, F.; Fatima, A. Degradation studies of azithromycin and its spectrophotometric determination in pharmaceutical dosage forms. Pak. J. Pharm. Sci., 2006, 19, 98-103.

29. Rufino, J.L.; Pezza, H.R.; Pezza, L. Flowinjection spectrophotometric determination of azithromycin in pharmaceutical formulations using p-chloranil in the presence of hydrogen peroxide. Anal. Sci., 2008, 24, 871-876.

30. Word Health Organization. WHO directorgeneral's opening remarks at the media briefing on COVID-19-(11 March 2020)., 2020. 